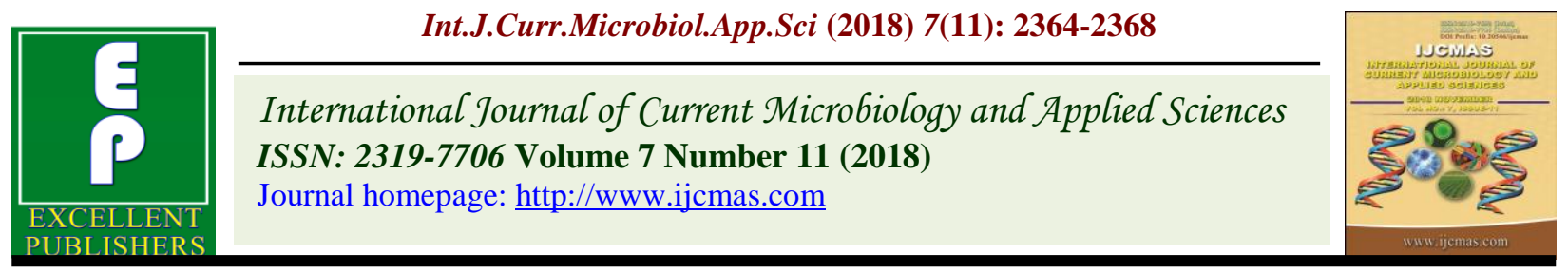

Original Research Article

https://doi.org/10.20546/ijcmas.2018.711.267

\title{
A Study on Production Constraints of Rice Cultivation in Kurnool District of Andhra Pradesh and Suggestions to Overcome Them
}

\author{
B. Affia Phenica*, T. Lakshmi, S.V. Prasad and Y. Reddi Ramu
}

Department of Agricultural Extension, S.V. Agricultural College, Tirupati-517502, Chittoor District, Andhra Pradesh, India

*Corresponding author

\section{A B S T R A C T}

Keywords

Production constraints, Rice farmers, Suggestions

Article Info

Accepted:

18 October 2018

Available Online:

10 November 2018
The present study was conducted in Kurnool district of Andhra Pradesh, to study the production constraints faced by rice farmers and various suggestions given by them to overcome the constraints. The major agro ecological, technical, socio-economical and marketing constraints perceived by farmers were high temperature during crop growth, scarcity of labour during peak periods, diversion of farmers from rice cultivation to irrigated dry crops and involvement of middlemen respectively. Important suggestions as given by the farmers were fetching better market price/provision of Minimum Support Price (MSP) by the government $(93.33 \%)$ was ranked first followed by prioritization of agricultural activities in MGNREGA scheme, development of pest and disease resistant varieties and development of suitable implements and equipments for all operations.

\section{Introduction}

Indian agriculture has undergone many noteworthy changes from a condition of begging bowl to self-sufficiency in the production of food grains. The first significant change is the attitude of the farmer towards farming. He considers it not merely as a way of life but also a kind of business. The second significant change is the interest of farmers in the adoption of new technology. The projections indicate that Indian population will be around two billion by 2050. Rising population and per capita income are obviously pushing up the food demand which needs to be met through enhanced productivity per unit area. In Andhra Pradesh area under rice mostly depends on the monsoon pattern and availability of water in reservoirs. The cultivable area under rice has alarmingly gone down to 5.67 lakh ha from 8 lakh ha (2017). There is no scope for increasing area under rice as rice area is replaced by some profitable dry crops due to insufficient water. The reasons for shrinking of paddy lands in the district are due to numerous constraints that are present in this aspect. Some of the farm level rice production constraints include stagnating yield, declining profit, high cost of labour, unavailability of the labour, unavailability of quality seed in time, marketing problems which in turn lead to distress sale, economic factors like price fluctuation and existing gap between rice grain and parboiled rice are adversely affecting rice 
production. Therefore, enhancing adaptability and stability of productivity and providing more entitlement to livelihood to the rice growing population is a major challenge to the agricultural research and development system. Keeping this in view, the production constraints faced by the farmers in rice cultivation was studied.

\section{Materials and Methods}

Kurnool district was purposively selected for the research study as it is the largest rice growing district in Rayalaseema region. Three mandals out of 54 mandals of Kurnool district were purposively selected for the study based on the highest area under rice cultivation. Four villages were selected from each mandal based on the highest area under rice cultivation thereby making a total of twelve villages for the study. From each selected village 10 members were selected randomly, thus making a total of 120 respondents for the study. The selected respondents were interviewed personally with the help of wellstructured interview schedule. Constraints faced by the rice farmers were classified in to four categories i.e., Agro-ecological, technical, socio-economic and marketing constraints. The responses were documented as 'major', 'medium' and 'minor' assigning scores of 3, 2 and 1 respectively.

\section{Results and Discussion}

The data in table 1 revealed that high temperature during crop growth (I rank), heavy rains at the time of harvest (II rank), conversion of paddy fields in to commercial ventures (III rank), drainage problems (IV rank), indiscriminate use of irrigation water (V rank), low fertility of the soil (VI rank) and intensive rice cultivation (VII rank) were the major agro-ecological constraints expressed by rice farmers in order of priority. The findings are in agreement with the findings of
Rahul (2016). The technical constraints were in the following rank order Scarcity of labour during peak periods (I rank), lack of proper local storage and processing facilities locally (II rank), high cost of labour (III rank), epidemics of pest and diseases (IV rank), weed infestation ( $\mathrm{V}$ rank), lack of awareness on various departmental subsidy schemes (VI rank), lack of custom hiring centers (VII rank), high cost of HYV/hybrid seed (VIII rank), hike in rental charges of certain farm machinery during peak season (IX rank), difficulty in using machinery in scattered \&fragmented plots (X rank), more occurrence of pests and diseases to stored grain (XI rank), difficulty to carryout repairs locally (XII rank), floods during crop period (XIII rank) and poor quality of seed (XIV rank). This finding is in accordance with the findings of Deepthi (2017).

Diversion of farmers from rice cultivation to irrigated dry crops (I rank), younger generation not interested in rice farming (II rank), high rate of interest on loan (III rank), high cost of inputs (IV rank), inadequate insurance coverage (V rank), untimely supply of inputs (VI rank), non-utilization of Farmers Call Center services by the farmers (VII rank), delay in advancing institutional finance (VIII rank) and poor extension services (IX rank) were the socio-economic constraints expressed by the rice farmers. The findings are in agreement with the findings of Sriharinarayana (2013).

With regard to the marketing constraints, involvement of middlemen (I rank), distress sale (II rank), dominance of millers in marketing the produce (III rank), lack of knowledge about market prices (IV rank), fluctuation in the market prices (V rank), very low MSP in paddy (VI rank) and lack of rice growers societies (VII rank). The result is in agreement with Aarathybalakrishnan (2011). 
Table.1 Production constraints faced by rice farmers

\begin{tabular}{|c|c|c|c|}
\hline S. No & Production Constraints & Score & Rank \\
\hline $\mathbf{A}$ & Agro-ecological constraints & & \\
\hline 1. & High temperature during crop growth & 292 & I \\
\hline 2. & Heavy rains at the time of harvest & 254 & II \\
\hline 3. & Conversion of paddy fields in to commercial venture & 205 & III \\
\hline 4. & Drainage problems & 146 & IV \\
\hline 5. & Indiscriminate use of irrigation water & 143 & $\mathrm{~V}$ \\
\hline 6. & Low fertility of the soil & 138 & VI \\
\hline 7. & Intensive rice cultivation & 135 & VII \\
\hline $\mathbf{B}$ & Technical constraints & & \\
\hline 1. & Scarcity of labour during peak periods & 356 & I \\
\hline 2. & Lack of proper local storage and processing facilities locally & 352 & II \\
\hline 3. & High cost of labour & 349 & III \\
\hline 4. & Epidemics of pest and diseases & 348 & IV \\
\hline 5. & Weed infestation & 344 & $\mathrm{~V}$ \\
\hline 6. & Lack of awareness on various departmental subsidy schemes & 344 & VI \\
\hline 7. & Lack of custom hiring centers & 341 & VII \\
\hline 8. & High cost of $\mathrm{HYV} /$ hybrid seed & 326 & VIII \\
\hline 9. & $\begin{array}{l}\text { Hike in rental charges of certain farm machinery during peak } \\
\text { season }\end{array}$ & 316 & IX \\
\hline 10. & Difficulty in using machinery in scattered \&fragmented plots & 315 & $\mathrm{X}$ \\
\hline 11. & More occurrence of pests and diseases to stored grain & 305 & $\mathrm{XI}$ \\
\hline 12. & Difficulty to carryout repairs locally & 258 & XII \\
\hline 13. & Floods during crop period & 218 & XIII \\
\hline 14. & Poor quality of seed & 157 & XIV \\
\hline $\mathrm{C}$ & Socio-Economic constraints & & \\
\hline 1. & $\begin{array}{l}\text { Diversion of farmers from rice cultivation to irrigated dry } \\
\text { crops }\end{array}$ & 348 & I \\
\hline 2. & Younger generation not interested in rice farming & 340 & II \\
\hline 3. & High rate of interest on loan & 327 & III \\
\hline 4. & High cost of inputs & 317 & IV \\
\hline 5. & Inadequate insurance coverage & 308 & $\mathrm{~V}$ \\
\hline 6. & Untimely supply of inputs & 281 & VI \\
\hline 7. & Non utilization of Farmers Call Center services by the farmers & 190 & VII \\
\hline 8. & Delay in advancing institutional finance & 180 & VIII \\
\hline 9. & Poor extension services & 164 & IX \\
\hline $\mathbf{D}$ & Marketing Constraints & & \\
\hline 1. & Involvement of middlemen & 339 & I \\
\hline 2. & Distress sale & 321 & II \\
\hline 3. & Dominance of millers in marketing the produce & 303 & III \\
\hline 4. & Lack of knowledge about market prices & 286 & IV \\
\hline 5. & Fluctuation in the market prices & 273 & $\mathrm{~V}$ \\
\hline 6. & $\begin{array}{l}\text { Very low MSP in paddy (in spite of increase in production } \\
\text { costs of paddy) }\end{array}$ & 219 & VI \\
\hline 7. & Lack of rice growers societies & 156 & VII \\
\hline
\end{tabular}


Table.2 Suggestions given by the rice farmers to overcome the production constraints

\begin{tabular}{|c|c|c|c|c|}
\hline S. No & Suggestions & $\mathbf{F}$ & $\%$ & Rank \\
\hline 1. & $\begin{array}{l}\text { Fetching better market price/provision of minimum support price } \\
\text { (MSP) by the government }\end{array}$ & 112 & 93.33 & $\mathrm{I}$ \\
\hline 2. & $\begin{array}{l}\text { Prioritization of agricultural activities in MGNREGA scheme } \\
\text { (Mahatma Gandhi National Rural Employment Guarantee Act) } \\
\text { to avoid labour shortage }\end{array}$ & 109 & 90.83 & II \\
\hline 3. & Development of pest and disease resistant varieties & 106 & 88.33 & III \\
\hline 4. & $\begin{array}{l}\text { Development of suitable implements and equipments for all } \\
\text { operations }\end{array}$ & 105 & 87.50 & IV \\
\hline 5. & Improvement in transportation and marketing facilities & 102 & 85.00 & V \\
\hline 6. & Establishment of custom hiring centers at local level & 101 & 84.16 & VI \\
\hline 7. & $\begin{array}{l}\text { Ensure public warehousing facilities in the vicinity of farmers } \\
\text { villages }\end{array}$ & 93 & 77.50 & VIII \\
\hline 8. & $\begin{array}{l}\text { Low cost of inputs (seeds, fertilizers, weedicides, pesticides, } \\
\text { diesel etc.) }\end{array}$ & 92 & 76.66 & IX \\
\hline 9. & Provision of loans by government agencies at lower interest rates & 85 & 70.83 & $\mathrm{XI}$ \\
\hline 10. & Provision of processing, trading and export facilities & 83 & 69.16 & XII \\
\hline 11. & Conducting regular farmer training programmes to the farmers & 80 & 66.66 & XIII \\
\hline 12. & Increasing subsidies for rice farming & 78 & 65.00 & XIV \\
\hline 13. & Encouraging seed village programme & 74 & 61.66 & XV \\
\hline 14. & Facilitating direct marketing in rice & 69 & 57.50 & XVI \\
\hline 15. & $\begin{array}{l}\text { Ensuring availability of High yielding variety (HYV) seed at } \\
\text { proper time }\end{array}$ & 66 & 55.00 & XVII \\
\hline 16. & Supply of good quality seed by Department of Agriculture & 64 & 53.33 & XVIII \\
\hline 17. & Adopting group farming approach in rice cultivation & 51 & 42.50 & $\mathrm{XX}$ \\
\hline 18. & Implementation of crop insurance schemes & 41 & 34.16 & XXII \\
\hline 19. & Recruitment of sufficient extension staff & 29 & 24.16 & XXIII \\
\hline
\end{tabular}

An overview of table 2 indicates the various suggestions given by farmers. Among the suggestions given by the farmers fetching better market price/provision of Minimum Support Price (MSP) by the government $(93.33 \%)$ was ranked first followed by prioritization of agricultural activities in MGNREGA scheme (90.83\%), development of pest and disease resistant varieties $(88.33 \%)$, development of suitable implements and equipments for all operations $(87.50 \%)$, improvement in transportation and marketing facilities (85.00\%), establishment of custom hiring centres at local level $(84.16 \%)$, ensure public warehousing facilities in the vicinity of farmers villages (77.50\%), low cost of inputs (seeds, fertilizers, weedicides, pesticides, diesel etc.) (76.66\%), provision of loans by government agencies at lower interest rates (70.83\%), provision of processing, trading and export facilities (69.16\%), conduct regular farmer training programmes $(66.66 \%)$, increase subsidies for rice farming $(65.00 \%)$, encourage seed village programme $(61.66 \%)$, facilitate direct marketing in rice $(57.50 \%)$, ensure timely supply of High Yielding Variety seed at proper time (55.00\%), supply of good quality seed by Department of Agriculture (53.33\%), adopt group farming 
approach in rice cultivation (42.50\%), implementation of crop insurance schemes $(34.16 \%)$, recruitment of sufficient and extension staff $(24.16 \%)$.

It is very much evident from the study that there existed a wide gap between development of technologies and their transfer to actual farming situations. Hence, these constraints perceived by the farmers could be overcome by following proper strategies like prioritization of agricultural works through MGNREGA, direct marketing, creation of proper storage facilities at panchayat or mandal levels, developing suitable farm machinery for small holdings, rice varieties resistant to lodging, specific pests and diseases and conducting on farm testing at different sites in order to develop effective adaptive research and technology verification capability. Apart from these providing credit facilities with low interest will encourage the farmers for extensive cultivation in the district.

\section{References}

Arathybalakrishnan. 2011. Constraint Analysis of rice farmers of Thrissur district of Kerala. M. Sc. (Ag.) Thesis,
Acharya N.G. Ranga Agricultural University, Hyderabad.

Ashok, G. 2012. Knowledge and adoption of system of rice intensification (SRI) technology among farmers in Nagapattinam district of Tamil Nadu. M.Sc. (Ag.) Thesis. Acharya N.G. Ranga Agricultural University, Hyderabad.

Deepthi, C., Raghunandareddy, G., Umadevi, K and Srinivasarao, V. 2017. Constraint analysis of small farmers in vegetable production in Guntur district. The Andhra Agricultural journal. 64 (2):454-458.

Rahulpawar, Madhuprasad, V.L., Shivalingegowga, N.S and Suresha, S.V. 2016. Constraints of Bt Cotton growers. Mysore Journal of Agricultural Sciences. 50 (4):768-769.

Saidhar R., Uma Devi, K., Vishnu Sankar Rao, D and Srinivasa Rao, V. 2016. Constraint Analysis of Small farmers in Agriculture in Guntur district of Andhra Pradesh. The Andhra Agriculture journal 63(4):962-967.

Sriharinarayana, N. 2013. Constraint Analysis of rice farmers of Nellore district of Andhra Pradesh. M.Sc. (Ag.) Thesis, Acharya N.G. Ranga Agricultural University, Hyderabad.

\section{How to cite this article:}

Affia Phenica, B., T. Lakshmi, S.V. Prasad and Reddi Ramu, Y. 2018. A Study on Production Constraints of Rice Cultivation in Kurnool District of Andhra Pradesh and Suggestions to Overcome Them. Int.J.Curr.Microbiol.App.Sci. 7(11): 2364-2368.

doi: https://doi.org/10.20546/ijcmas.2018.711.267 